\title{
Two New Triterpenoid Glycosides Isolated from Aesculus assamica GRIFF
}

\author{
Hongwei Liu, ${ }^{*, a}$ Xue Zhang, ${ }^{b}$ Hao GAO, ${ }^{b}$ Nali Wang, ${ }^{b, d}$ Sanlin JIN, ${ }^{b}$ Bin CAI, ${ }^{c}$ Xinsheng YAO, ${ }^{*, b, d}$ and \\ Guoping $\mathrm{CAI}^{a}$ \\ ${ }^{a}$ Life Science Division, Graduate School at Shenzhen, Tsinghua University; The University Town, Shenzhen 518055, \\ People's Republic of China: ${ }^{b}$ Shenzhen Research Center of Traditional Chinese Medicine and Natural Products; The \\ University Town, Shenzhen 518055, People's Republic of China: ' ${ }^{c}$ Laboratory of Bioactive Assay, Tianjin Institute of \\ Biomedicine; Tianjin 300384, People's Republic of China: and ${ }^{d}$ Department of Natural Product Chemistry, Shenyang \\ Pharmaceutical University; Wenhua-Road 103, Shenyang 110016, People's Republic of China.
}

Received January 17, 2005; accepted June 13, 2005

\begin{abstract}
Phytochemical study of the ethanol extract of the seeds of Aesculus assamica led to the isolation of two new triterpenoid saponins. The structure of the new compounds were elucidated on the basis of spectral data to be 28- $O$-acetyl-21- $O$-(4-O-angeloyl)-6-deoxy- $\beta$-glucopyranosyl-3- $O$ - $[\beta$-glucopyranosyl $(1-2)-O$ - $[\beta$-glucopyranosyl $(1-4)]$ - $\beta$-glucuronopyranosyl]protoaescigenin $(1)$, and 21- $O$-(4- $O$-angeloyl)-6-deoxy- $\beta$-glucopyranosyl-3- $O$ $[\beta$-glucopyranosyl $(1-2)-O$-[ $\beta$-glucopyranosyl $(1-4)]-\beta$-glucuronopyranosyl]protoaescigenin (2). Their in vitro bioactivity against plant pathogenic fungus Pyricularia oryzae and cytotoxicity against K562 and HCT-15 cell lines were evaluated.
\end{abstract}

Key words triterpenoid glycoside; Aesculus assamica; anti-fungal activity; cytotoxicity

The plants of Aesculus genus (Family Hippocastanaceae) have attracted much interests of phytochemists for many years due to the discovery of acylated triterpenoid saponinsescins with extraordinary anti-inflammatory activity from horse chestnut (Aesculus hippocastanum L.) seeds and the successful applications of its seeds extract for treatment of peripheral chronic venous insufficiency or as ingredients in cosmetics. The Aesculus genus consists of about thirty species distributed in Asia, Europe and America. There are sixteen species distributed in China, and most of them are used as herbal medicines for the treatment of distention and pain in the chest and abdomen. A number of escins-like saponins have been isolated from plants of this genus, ${ }^{1-11)}$ and of which various biological activities have been studied and reported, such as anti-inflammatory, hypoglycemic activities, inhibitory effects on ethanol absorption, as well as antiHIV-1 protease activities. During our search for a substitute in China, we did phytochemical investigation on the seeds of A. assamica GRIFF, a plant distributed in Yunnan Province of China. Two novel triterpenoid saponins with insulin-like activity, termed assamicins I and II, have been isolated from A. assamica ${ }^{12)}$ Herein, we describe the isolation, structure determination, and bioactivies of two new triterpenoid saponins, designated as assamicin III and IV.

\section{Results and Discussion}

The $95 \%$ EtOH extracts of $A$. assamica were separated as described in Experimental to yield compounds 1 and 2, 28$O$-acetyl-21- $O$-(4- $O$-angeloyl)-6-deoxy- $\beta$-glucopyranosyl-3$O$-[ $\beta$-glucopyranosyl $(1-2)-O$-[ $\beta$-glucopyranosyl $(1-4)]-\beta$ glucuronopyranosyl]protoaescigenin (1) and 21-O-(4-O-angeloyl)-6-deoxy- $\beta$-glucopyranosyl-3- $O$-[ $\beta$-glucopyranosyl $(1-2)-O$-[ $\beta$-glucopyranosyl $(1-4)]-\beta$-glucuronopyranosyl]protoaescigenin (2) (Fig. 1).

Compound $\mathbf{1}$ was isolated as a white amorphous powder. Its IR spectrum showed absorption bands due to hydroxyl, carboxyl, ester, and olefin functions at 3409, 1724, 1720, 1678,1654 and $1648 \mathrm{~cm}^{-1}$, and two broad absorption bands at 3409 and $1049 \mathrm{~cm}^{-1}$ suggested the possible existence of a glycosidic structure. High resolution FAB-MS revealed the molecular formula of $\mathbf{1}$ to be $\mathrm{C}_{61} \mathrm{H}_{96} \mathrm{O}_{28}$. In the positive ESIMS of 1, quasimolecular ion peak was observed at $m / z 1299$ $[\mathrm{M}+\mathrm{Na}]^{+}$. The positive-ion ESI-MS ${ }^{2)}$ spectrum of $m / z 1299$ gave ions at $m / z \quad 1137 \quad[\mathrm{M}+\mathrm{Na}-162]^{+}, \quad 1077$ $[\mathrm{M}+\mathrm{Na}-60-162]^{+}, 915[\mathrm{M}+\mathrm{Na}-60-162-162]^{+}, 739$ $[\mathrm{M}+\mathrm{Na}-60-162-162-176]^{+}, \quad 511 \quad[\mathrm{M}+\mathrm{Na}-60-162-$ $162-176-228]^{+}$, indicating the sequential losses of hexose units. The ${ }^{1} \mathrm{H}$ - and ${ }^{13} \mathrm{C}$-NMR signals of $\mathbf{1}$ showed a close resemblance to those of isoescin $\mathrm{Ib}$ that contains trisaccharide moiety attached at the $\mathrm{C}-3$ of protoaescigenin skeleton. ${ }^{8)} \mathrm{Al}-$ kaline hydrolysis of 1 with $10 \%$ aqueous potassium hydroxide in $50 \%$ aqueous dioxane $(1: 1)$ produced the deacylated saponin that was purified by silica gel preparative TLC. The amount of deacylated saponin obtained was too little to get the good NMR data, it was only analyzed by ESI-MS/MS spectrum $\quad\left(1157 \quad[\mathrm{M}+\mathrm{Na}]^{+}, \quad 995 \quad[\mathrm{M}+\mathrm{Na}-162]^{+}, 833\right.$ $[\mathrm{M}+\mathrm{Na}-162-162]^{+}, 657[\mathrm{M}+\mathrm{Na}-162-162-176]^{+}, 511$ $\left.[\mathrm{M}+\mathrm{Na}-162-162-176-146]^{+}\right)$. The further acid hydrolysis of the deacylated saponin liberated aglycone and sugars. 6-Deoxy-glucose, glucose and glucuronic acid were identified by paper chromatography and GC in comparison with authentics, and a mixture of sapogenins including protoaescigenin were detected by TLC comparison with authentics. ${ }^{8,11}$ The ${ }^{1} \mathrm{H}$ - and ${ }^{13} \mathrm{C}$-NMR signals were assigned by a combination of DEPT, COSY, TOSCY, HMQC, HMBC, and NOESY spectra, which included signals due to the protoaescigenin skeleton [ ${ }^{1} \mathrm{H}-\mathrm{NMR}$ : 0.63 (Me-25), 0.71 (Me-26), 1.24 (Me23), 1.48 (Me-29), 1.30 (Me-30) and a broad signal at 5.38 (H-12)], four sugar moieties [ ${ }^{1} \mathrm{H}-\mathrm{NMR}: \beta$-anomeric protons at $4.85\left(\mathrm{~d}, J=7.6 \mathrm{~Hz}, \mathrm{H}-1^{\prime}\right), 5.53\left(\mathrm{~d}, J=7.6 \mathrm{~Hz}, \mathrm{H}-1^{\prime \prime}\right), 5.18$ $\left(\mathrm{d}, J=7.2 \mathrm{~Hz}, \mathrm{H}-1^{\prime \prime \prime}\right)$, and $4.90\left(\mathrm{~d}, J=7.6 \mathrm{~Hz}, \mathrm{H}-1^{\prime \prime \prime \prime}\right) ;{ }^{13} \mathrm{C}-$ NMR: anomeric carbons at 104.7 (C-1'), $104.5\left(\mathrm{C}-1^{\prime \prime}\right), 104.6$ $\left(\mathrm{C}-1^{\prime \prime \prime}\right)$, and $\left.105.9\left(\mathrm{C}-1^{\prime \prime \prime \prime}\right)\right]$, an acetyl group [ ${ }^{1} \mathrm{H}-\mathrm{CMR}: 2.32$ (s, 3H, acetyl-28), $\left.{ }^{13} \mathrm{C}-\mathrm{NMR}: 169.4(\mathrm{C}=\mathrm{O}-28)\right]$, and an angeloyl group [ ${ }^{1} \mathrm{H}-\mathrm{NMR}: 1.92\left(\mathrm{~d}, 3 \mathrm{H}, J=1.6 \mathrm{~Hz}, \mathrm{Me}-3^{\prime \prime \prime \prime \prime}\right)$, 1.99 (dd, 3H, $\left.J=1.6,7.2 \mathrm{~Hz}, \mathrm{Me}-5^{\prime \prime \prime \prime \prime}\right), 5.94\left(\mathrm{~m}, \mathrm{H}-4^{\prime \prime \prime \prime \prime \prime}\right) ;{ }^{13} \mathrm{C}-$ NMR: $\left.128.3\left(\mathrm{C}-2^{\prime \prime \prime \prime \prime}\right), 137.8\left(\mathrm{C}-4^{\prime \prime \prime \prime \prime}\right), 167.4\left(\mathrm{C}=\mathrm{O}-1^{\prime \prime \prime \prime \prime}\right)\right]$. The larger coupling constant for $\mathrm{H}-4^{\prime \prime \prime \prime \prime}$ at $5.32(\mathrm{t}, J=9.6 \mathrm{~Hz})$ to- 


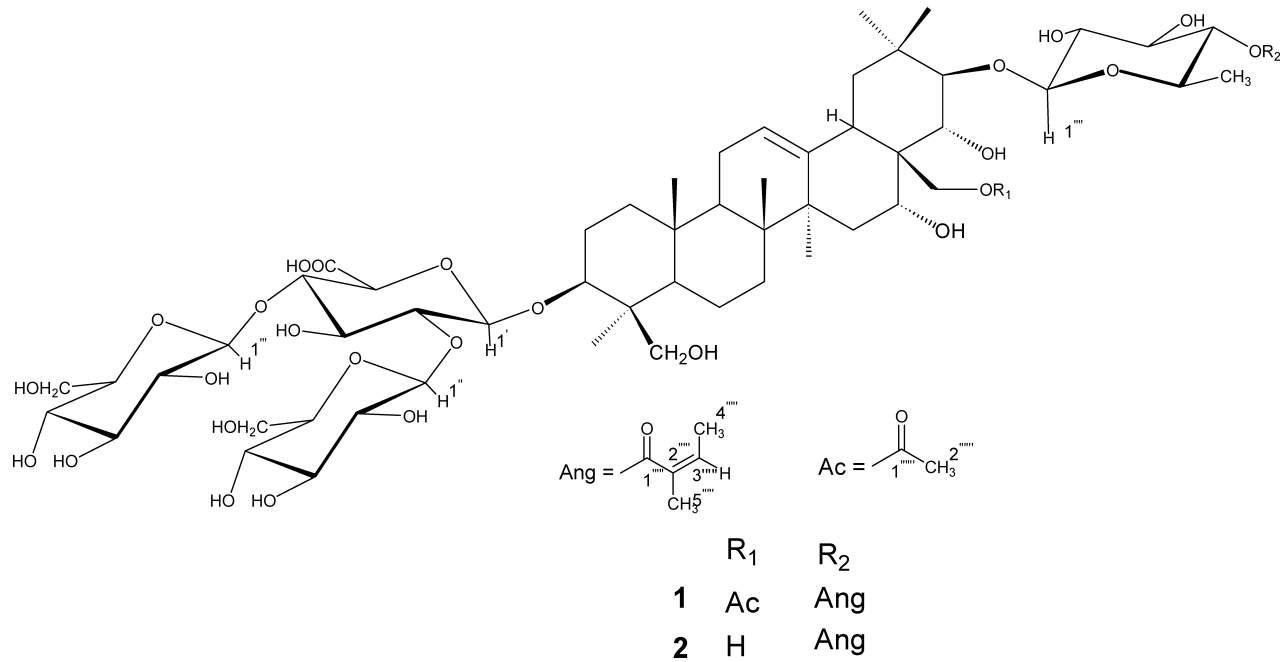

Fig. 1. Structures of Compounds $\mathbf{1}$ and $\mathbf{2}$

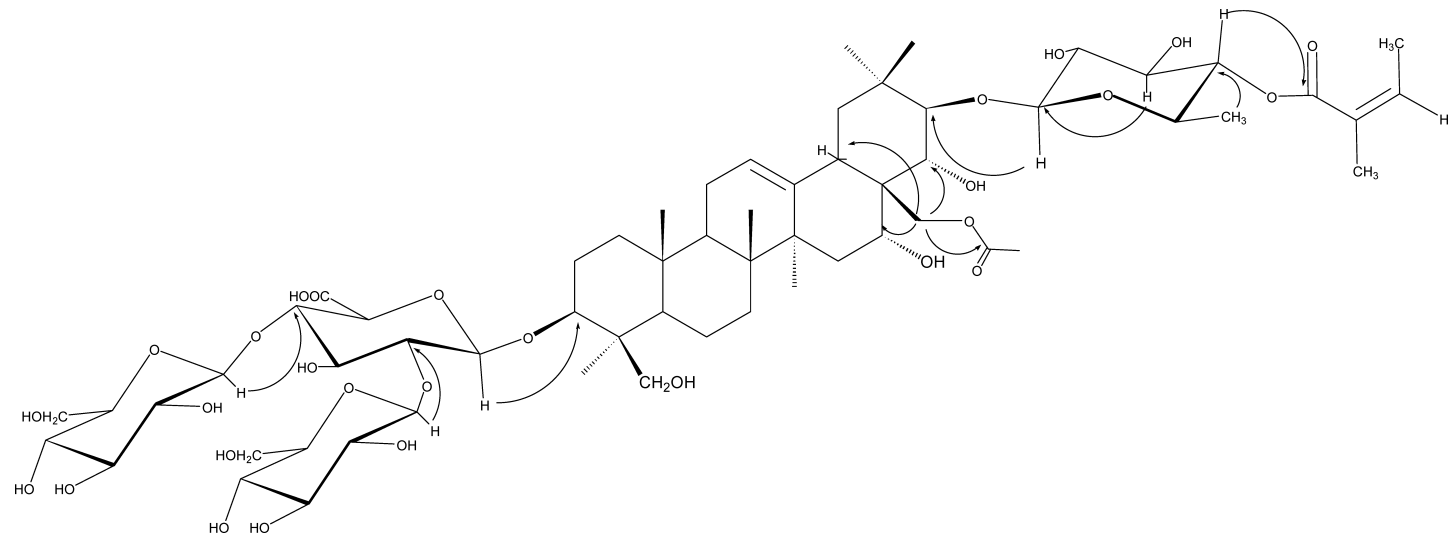

Fig. 2. Key HMBC Correlations of Compound $\mathbf{1}$

gether with $\mathrm{HMBC}$ correlation observed between $\mathrm{CH}_{3}-6^{\prime \prime \prime \prime}$ and $\mathrm{C}-4^{\prime \prime \prime \prime}$ indicated the presence of 6 -deoxy- $\beta$-glucose, which was also confirmed by comparison with NMR data of assamicin II. ${ }^{12)}$ The position of sugar moiety at C-3 and C-21 and interlinking among sugar moiety were deduced from HMBC experiments, in which $\mathrm{H}-1^{\prime}, \mathrm{H}-1^{\prime \prime}, \mathrm{H}-1^{\prime \prime \prime}$, and $\mathrm{H}-1^{\prime \prime \prime \prime}$ were correlated with C-3 (90.8), C-2' (78.4), C-4' (82.0), and $\mathrm{C}-21$ (90.8). The position of acetyl and angeloyl groups at $\mathrm{C}$ 28 and C-4"'" were also deduced from HMBC spectrum as indicated in Fig. 2. The relative stereochemistry of $\mathbf{1}$ was confirmed to be the same as that of assamicin I and II by NOESY experiment. In its NOESY spectrum, Me-29 showed a strong correlation with $\mathrm{H}-21$, while Me-30 correlated strongly with $\mathrm{H}-22$ at $4.60(\mathrm{~d}, J=9.6 \mathrm{~Hz})$. These indicated the $\alpha$ configuration of $\mathrm{H}-21$ and $\beta$ configuration of $\mathrm{H}-22$. The coupling constant of $\mathrm{H}-21$ and $\mathrm{H}-22(J=10.0 \mathrm{~Hz})$ also supported the proposed structure. On the basis of the above evidence, the structure of compound 1 was determined to be 28$O$-acetyl-21- $O$-(4- $O$-angeloyl)-6-deoxy- $\beta$-glucopyranosyl-3$O$-[ $\beta$-glucopyranosyl $(1-2)-O$ - $[\beta$-glucopyranosyl $(1-4)]-\beta$ glucuronopyranosyl]protoaescigenin, and designated as assamicin III.

Compound 2 was isolated as amorphous powder. The molecular formula, $\mathrm{C}_{59} \mathrm{H}_{94} \mathrm{O}_{27}$, was determined on the basis of the HR-FAB-MS spectrum. In the positive ESI-MS of 1, qua- simolecular ion peak was observed at $m / z 1257[\mathrm{M}+\mathrm{Na}]^{+}$. The positive-ion ESI-MS ${ }^{2)}$ spectrum of $\mathrm{m} / z 1257$ gave ions at $m / z 1095[\mathrm{M}+\mathrm{Na}-162]^{+}, 933[\mathrm{M}+\mathrm{Na}-162-162]^{+}, 757$ $[\mathrm{M}+\mathrm{Na}-162-162-176]^{+}, 529[\mathrm{M}+\mathrm{Na}-162-162-176-$ $228]^{+}$, indicating the sequential losses of hexose units. The IR, ${ }^{1} \mathrm{H}$ - and ${ }^{13} \mathrm{C}$-NMR spectrum of 2 showed very similarity to that of 1, except for the loss of acetyl group at C-28. In summary, the characteristic signals of protoaescigenin skeleton including five methyl groups at $\delta$ [0.66 (Me-25), 0.82 (Me-26), 1.24 (Me-23), 1.51 (Me-29), 1.35 (Me-30) and a broad signal at $\delta 5.37$ (H-12)], four anomeric protons of sugar moieties at $\delta\left[4.88\left(\mathrm{~d}, J=8.0 \mathrm{~Hz}, \mathrm{H}-1^{\prime}\right), 5.51\right.$ (d, $\left.J=7.6 \mathrm{~Hz}, \mathrm{H}-1^{\prime \prime}\right), 5.18\left(\mathrm{~d}, J=7.6 \mathrm{~Hz}, \mathrm{H}-1^{\prime \prime \prime}\right)$, and $4.86(\mathrm{~d}$, $\left.\left.J=8.0 \mathrm{~Hz}, \mathrm{H}-1^{\prime \prime \prime \prime}\right)\right]$, and a angeloyl signals at $\delta[1.89(\mathrm{~d}, 3 \mathrm{H}$, $\left.J=1.6 \mathrm{~Hz}, \mathrm{Me}-3^{\prime \prime \prime \prime \prime}\right), 1.99$ (dd, 3H, $\left.J=1.6,7.2 \mathrm{~Hz}, \mathrm{Me}-5^{\prime \prime \prime \prime \prime}\right)$, and $\left.5.93\left(\mathrm{dq}, J=1.6,7.2 \mathrm{~Hz}, \mathrm{H}-4^{\prime \prime \prime \prime \prime \prime}\right)\right]$ were observed in its ${ }^{1} \mathrm{H}$ NMR spectrum, and so was their corresponding carbon signals in the ${ }^{13} \mathrm{C}$-NMR spectrum of 2 . The whole structure of 2 was established from HMBC analysis, and signal assignments were accomplished in combination of COSY, TOCSY, HMQC, HMBC and NOESY spectral analysis. Compound 2 possess the same stereochemistry as that of $\mathbf{1}$, which can be deduced from NOESY experiments. Based on the above analysis and comparison with the NMR data of $\mathbf{1}$, compound 2 was identified as 21-O-(4- $O$-angeloyl)-6-deoxy- $\beta$-glucopy- 
Table 1. ${ }^{13} \mathrm{C}-\mathrm{NMR}$ Data of Compounds $\mathbf{1}$ and $\mathbf{2}$ (ppm, $100 \mathrm{MHz}$ in $\left.\mathrm{C}_{5} \mathrm{D}_{5} \mathrm{~N}\right)$

\begin{tabular}{|c|c|c|c|c|c|}
\hline No. & 1 & 2 & No. & 1 & 2 \\
\hline 1 & 38.3 & 38.5 & $1^{\prime}$ & 104.7 & 104.7 \\
\hline 2 & 26.4 & 26.5 & $2^{\prime}$ & 78.4 & 78.5 \\
\hline 3 & 90.8 & 90.8 & $3^{\prime}$ & 76.8 & 76.8 \\
\hline 4 & 43.7 & 43.8 & $4^{\prime}$ & 82.0 & 81.9 \\
\hline 5 & 55.9 & 56.0 & $5^{\prime}$ & 76.2 & 76.2 \\
\hline 6 & 18.4 & 18.5 & $6^{\prime}$ & 172.5 & 172.5 \\
\hline 7 & 33.0 & 33.1 & $1^{\prime \prime}$ & 104.5 & 104.5 \\
\hline 8 & 39.8 & 39.9 & $2^{\prime \prime}$ & 73.5 & 73.3 \\
\hline 9 & 46.7 & 46.8 & $3^{\prime \prime}$ & 78.4 & 78.4 \\
\hline 10 & 36.2 & 36.3 & $4^{\prime \prime}$ & 70.9 & 70.9 \\
\hline 11 & 23.9 & 24.0 & $5^{\prime \prime}$ & 78.0 & 78.0 \\
\hline 12 & 122.9 & 122.9 & $6^{\prime \prime}$ & 62.2 & 62.2 \\
\hline 13 & 141.8 & 143.7 & $1^{\prime \prime \prime}$ & 104.6 & 104.6 \\
\hline 14 & 41.2 & 41.8 & $2^{\prime \prime \prime}$ & 74.8 & 74.8 \\
\hline 15 & 31.0 & 34.5 & $3^{\prime \prime \prime}$ & 78.4 & 78.4 \\
\hline 16 & 71.9 & 67.9 & $4^{\prime \prime \prime}$ & 71.4 & 71.4 \\
\hline 17 & 46.9 & 47.8 & $5^{\prime \prime \prime}$ & 78.4 & 78.4 \\
\hline 18 & 39.2 & 40.3 & $6^{\prime \prime \prime}$ & 62.3 & 62.3 \\
\hline 19 & 47.8 & 48.1 & $1^{\prime \prime \prime \prime}$ & 105.9 & 106.0 \\
\hline 20 & 37.0 & 37.1 & $2^{\prime \prime \prime \prime}$ & 75.3 & 75.3 \\
\hline 21 & 90.8 & 92.0 & $3^{\prime \prime \prime \prime}$ & 75.6 & 75.8 \\
\hline 22 & 70.9 & 73.4 & $4^{\prime \prime \prime \prime}$ & 76.3 & 76.3 \\
\hline 23 & 22.4 & 22.5 & $5^{\prime \prime \prime \prime}$ & 70.7 & 70.4 \\
\hline 24 & 63.3 & 63.4 & $6^{\prime \prime \prime \prime}$ & 17.8 & 18.0 \\
\hline 25 & 15.5 & 15.6 & $1^{\prime \prime \prime \prime \prime \prime}$ & 167.4 & 167.4 \\
\hline 26 & 16.5 & 16.6 & $2^{\prime \prime \prime \prime \prime \prime}$ & 128.3 & 128.3 \\
\hline 27 & 26.9 & 27.4 & $3^{\prime \prime \prime \prime \prime \prime}$ & 20.6 & 20.6 \\
\hline 28 & 64.6 & 66.7 & $4^{\prime \prime \prime \prime \prime \prime}$ & 137.8 & 137.7 \\
\hline 29 & 29.9 & 29.9 & $5^{\prime \prime \prime \prime \prime \prime}$ & 15.8 & 15.8 \\
\hline \multirow[t]{2}{*}{30} & 19.6 & 20.2 & $1^{\prime \prime \prime \prime \prime \prime \prime \prime}$ & 169.4 & \\
\hline & & & $2^{\prime \prime \prime \prime \prime \prime \prime}$ & 22.0 & \\
\hline
\end{tabular}

ranosyl-3- $O$ - $[\beta$-glucopyranosyl( $1-2)-O$ - $[\beta$-glucopyranosyl $(1-4)]$ - $\beta$-glucuronopyranosyl]protoaescigenin (2), and named as assamicin IV.

Compounds $\mathbf{1}$ and $\mathbf{2}$ exhibited moderate activity against the plant pathogenic fungus Pyricularia oryzae with the minimal morphological deformation concentration (MMDC) values of 100 and $120 \mu \mathrm{M}$, respectively. A weak cytotoxicity on K562 and HCT-15 cell lines for $\mathbf{1}$ and $\mathbf{2}$ was observed $\left(\mathrm{IC}_{50}\right.$ $>100 \mu \mathrm{g} / \mathrm{ml})$.

\section{Experimental}

General Experimental Procedure Melting points were determined on a Yanaco MP-S $\mathrm{S}_{3}$ micromelting point apparatus, and were uncorrected. Optical rotations were measured using a P-1020 digital polarimeter (JASCO corporation). FAB-MS and HR-MS were obtained using a JEOL JMS-DX302 spectrometer. ESI-MS was conduced using Bruker esquire 2000 mass spectrometer. IR spectra were recorded on SHIMADZU FT/IR-8400 spectrometer. ${ }^{1} \mathrm{H}$ - and ${ }^{13} \mathrm{C}-\mathrm{NMR}$, along with $2 \mathrm{D}$ NMR spectra were obtained on a Bruker AV-400 $\left(400 \mathrm{MHz}\right.$ for ${ }^{1} \mathrm{H}, 100 \mathrm{MHz}$ for $\left.{ }^{13} \mathrm{C}\right) \mathrm{NMR}$ spectrometer, using TMS as an internal standard. Chemical shifts were expressed in $\delta$ (ppm) and coupling constants $(J)$ were reported in Hertz (Hz). GC was done on a HP-5890 SERIES II spectrometer, with a SE30 capillary column $(12 \mathrm{~m}$, $0.22 \mathrm{~mm}$ i.d.), hydrogen flame ionization detector (FID, $270^{\circ}$ ), the column temperature was $170-250{ }^{\circ} \mathrm{C}$ with the rate of $5{ }^{\circ} \mathrm{C} / \mathrm{min}$, and the carrier gas was $\mathrm{N}_{2}(30 \mathrm{ml} / \mathrm{min})$. TLC was carried out on Silica gel $60 \mathrm{~F}_{254}$ and the spots were visualized by sprayed with $10 \% \mathrm{H}_{2} \mathrm{SO}_{4}$ and heating. Diaion HP-20 (Mitsubishi Kasei) and ODS (Lobar, $40-63 \mu \mathrm{m}$, Merck) were used for column chromatography. Preparative HPLC was performed using an ODS column (C-18, 250×20 mm, SHIMADZU Pak; detector: RID). Minimum essential medium (MEM) was obtained from Gibco and fetal calf serum (FCS) from Tianjin Chuanyie Bio-engineering Co. (Tianjin, China)

Exraction and Isolation The powdered seeds $(2.0 \mathrm{~kg})$ were extracted three times with $70 \% \mathrm{EtOH}$ under reflux for $2 \mathrm{~h}$. After removal of the sol- vent in vacuo, the extract $(250 \mathrm{~g})$ was further partitioned between $\mathrm{H}_{2} \mathrm{O}$ and EtOAc to give $\mathrm{H}_{2} \mathrm{O}$-soluble and EtOAc-soluble fractions. The $\mathrm{H}_{2} \mathrm{O}$-soluble $(180 \mathrm{~g})$ fraction was subjected to HP-20 resin column chromatography and eluted successively with $\mathrm{H}_{2} \mathrm{O}, 30 \% \mathrm{EtOH}, 50 \% \mathrm{EtOH}, 70 \% \mathrm{EtOH}, 95 \%$ $\mathrm{EtOH}$, and $100 \%$ acetone to afford 6 fractions. The second fraction $(50 \%$ EtOH eluate, $10 \mathrm{~g}$ ) was further separated by ODS column eluted with $30 \%$ $\mathrm{MeOH}, 50 \% \mathrm{MeOH}, 70 \% \mathrm{MeOH}, 100 \% \mathrm{MeOH}$ to give 10 subfractions. The third subfraction $(50 \% \mathrm{MeOH}$ eluate, $0.1 \mathrm{~g})$ containing the high polar triterpenoid saponins was purifed by preparative HPLC [MeOH- $0.1 \%$ TFA aqueous solution $(65: 35, \mathrm{v} / \mathrm{v})$, flow rate, $30 \mathrm{ml} / \mathrm{min}]$ to yield $\mathbf{1}(5 \mathrm{mg})$ and 2 $(6 \mathrm{mg})$. The other parts are undergoing further separation.

Assamicin III (1): Amorphous powder, $[\alpha]_{\mathrm{D}}^{24}-47.8^{\circ}(c=0.2$, pyridine). HR-FAB-MS $m / z \quad[\mathrm{M}+\mathrm{Na}]^{+} 1299.5186$ (Calcd for $\mathrm{C}_{61} \mathrm{H}_{96} \mathrm{O}_{28} \mathrm{Na}$ : 1299.5165). Positive-ESI-MS (m/z): $1299[\mathrm{M}+\mathrm{Na}]^{+}, 1071,981,799,661$. Negative-ESI-MS $(\mathrm{m} / \mathrm{z}): 1275[\mathrm{M}-\mathrm{H}]^{-}$. IR $(\mathrm{KBr}) \mathrm{cm}^{-1}: 3409,2947,1724$, $1720,1678,1654,1648,1380,1238,1049 .{ }^{1} \mathrm{H}-\mathrm{NMR}$ (pyridine- $d_{5}$ ) $\delta: 3.29$ $(1 \mathrm{H}, \mathrm{m}, \mathrm{H}-3), 5.38(1 \mathrm{H}$, brs, $\mathrm{H}-6), 5.93(1 \mathrm{H}, \mathrm{m}, \mathrm{H}-16), 2.96(2 \mathrm{H}, \mathrm{d}$, $J=10.8 \mathrm{~Hz}, \mathrm{H}-18), 4.17(1 \mathrm{H}, \mathrm{m}, \mathrm{H}-21), 4.6(1 \mathrm{H}, \mathrm{d}, J=9.6 \mathrm{~Hz}, \mathrm{H}-22), 1.24$ $(3 \mathrm{H}, \mathrm{s}, \mathrm{H}-23), 3.29(1 \mathrm{H}, \mathrm{m}, \mathrm{H}-24), 4.22(1 \mathrm{H}, \mathrm{m}, \mathrm{H}-24), 0.63(3 \mathrm{H}, \mathrm{s}, \mathrm{H}-25)$, $0.71(3 \mathrm{H}, \mathrm{s}, \mathrm{Me}-26), 1.48(3 \mathrm{H}, \mathrm{s}, \mathrm{Me}-27), 3.60(1 \mathrm{H}, \mathrm{d}, J=12.0 \mathrm{~Hz}, \mathrm{H}-28)$, $3.92(1 \mathrm{H}, \mathrm{m}, \mathrm{H}-28), 1.48(3 \mathrm{H}, \mathrm{s}, \mathrm{H}-29), 1.30(3 \mathrm{H}, \mathrm{s}, \mathrm{H}-30), 4.85$ (d, $J=7.6$ $\left.\mathrm{Hz}, \mathrm{H}-1^{\prime}\right), 5.53$ (d, $\left.J=7.6 \mathrm{~Hz}, \mathrm{H}-1^{\prime \prime}\right), 5.18$ (d, $\left.J=7.2 \mathrm{~Hz}, \mathrm{H}-1^{\prime \prime \prime}\right)$, and 4.90 (d, $\left.J=7.6 \mathrm{~Hz}, \mathrm{H}-1^{\prime \prime \prime \prime}\right), 5.32\left(\mathrm{t}, J=9.6 \mathrm{~Hz}, \mathrm{H}-4^{\prime \prime \prime \prime}\right), 3.90$ (dq, $\left.J=6.0,9.6 \mathrm{~Hz}, \mathrm{H}-5^{\prime \prime \prime \prime}\right)$, 2.32 (s, 3H, acetyl-28), 1.92 (d, 3H, $\left.J=1.6 \mathrm{~Hz}, \mathrm{Me}-3^{\prime \prime \prime \prime \prime}\right), 1.99$ (dd, $3 \mathrm{H}$, $\left.J=1.6,7.2 \mathrm{~Hz}, \mathrm{Me}-5^{\prime \prime \prime \prime \prime}\right), 5.94$ (m, H-4"'"') ).

Assamicin IV (2): Amorphous powder, $[\alpha]_{D}^{24}-40.5^{\circ}(c=0.2$, pyridine). HR-FAB-MS $m / z \quad[\mathrm{M}+\mathrm{Na}]^{+} 1257.4568$ (Calcd for $\mathrm{C}_{60} \mathrm{H}_{94} \mathrm{O}_{27} \mathrm{Na}$,

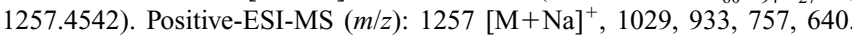
Negative-ESI-MS $(\mathrm{m} / \mathrm{z}): 1233[\mathrm{M}-\mathrm{H}]^{-}$. IR $(\mathrm{KBr}) \mathrm{cm}^{-1}: 3409,2947,1724$, $1678,1654,1648,1380,1045 .{ }^{1} \mathrm{H}-\mathrm{NMR}$ (pyridine- $\left.d_{5}\right) \delta: 3.33(1 \mathrm{H}, \mathrm{m}, \mathrm{H}-3)$, $5.37(1 \mathrm{H}$, br s, H-6), $4.98(1 \mathrm{H}$, br s, H-16), $2.96(2 \mathrm{H}, \mathrm{dd}, J=4.0,11.6 \mathrm{~Hz}, \mathrm{H}-$ 18), $4.79(1 \mathrm{H}, \mathrm{d}, J=9.6 \mathrm{~Hz}, \mathrm{H}-21), 4.62(1 \mathrm{H}, \mathrm{d}, J=9.6 \mathrm{~Hz}, \mathrm{H}-22), 1.24(3 \mathrm{H}$, s, H-23), $3.32(1 \mathrm{H}, \mathrm{m}, \mathrm{H}-24), 4.22(1 \mathrm{H}, \mathrm{m}, \mathrm{H}-24), 0.66$ (3H, s, H-25), 0.82 ( $3 \mathrm{H}, \mathrm{s}, \mathrm{Me}-26), 1.83$ (3H, s, Me-27), 3.67 (1H, d, $J=11.8 \mathrm{~Hz}, \mathrm{H}-28), 3.79$ $(1 \mathrm{H}, \mathrm{d}, J=11.8 \mathrm{~Hz}, \mathrm{H}-28), 1.51(3 \mathrm{H}, \mathrm{s}, \mathrm{H}-29), 1.35(3 \mathrm{H}, \mathrm{s}, \mathrm{H}-30), 4.88(\mathrm{~d}$, $\left.J=8.0 \mathrm{~Hz}, \mathrm{H}-1^{\prime}\right), 5.51$ (d, $\left.J=7.6 \mathrm{~Hz}, \mathrm{H}-1^{\prime \prime}\right), 5.18$ (d, $\left.J=7.6 \mathrm{~Hz}, \mathrm{H}-1^{\prime \prime \prime}\right)$, and $4.86\left(\mathrm{~d}, J=8.0 \mathrm{~Hz}, \mathrm{H}-1^{\prime \prime \prime}\right), 5.32$ (t, $\left.J=9.6 \mathrm{~Hz}, \mathrm{H}-4^{\prime \prime \prime \prime}\right), 3.62$ (dq, $J=6.0$, $\left.9.6 \mathrm{~Hz}, \mathrm{H}-5^{\prime \prime \prime \prime}\right), 1.92$ (d, $\left.3 \mathrm{H}, J=1.6 \mathrm{~Hz}, \mathrm{Me}-3^{\prime \prime \prime \prime \prime}\right), 1.99$ (dd, $3 \mathrm{H}, J=1.6,7.2 \mathrm{~Hz}$,

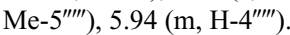

Alkaline and Acid Hydrolysis of Saponins A solution of saponin (1 and $2,4 \mathrm{mg}$ each) in $10 \%$ aqueous $\mathrm{KOH}-50 \%$ aqueous dioxane $(1: 1, \mathrm{v} / \mathrm{v}$, $2 \mathrm{ml}$ ) was stirred at $37^{\circ} \mathrm{C}$ for $1 \mathrm{~h}$. The reaction mixture was neutralized with $10 \%$ acetic acid. After removal of the solvent from the filtrate under reduced pressure, the residue was dissolved in $\mathrm{H}_{2} \mathrm{O}(5 \mathrm{ml})$ and extracted with EtOAc: $\mathrm{BuOH}(1: 1)$. The organic solvents were evaporated and purified by Preparative TLC on silica gel $\left(\mathrm{CHCl}_{3}: \mathrm{MeOH}: \mathrm{H}_{2} \mathrm{O}, 70: 30: 5\right)$ to give the deacylated saponin (about $1.5 \mathrm{mg}$ ) for $\mathbf{1}$ and $\mathbf{2}$. The product was redissolved in $\mathrm{H}_{2} \mathrm{O}(1 \mathrm{ml})$ and treated with $20 \%$ aqueous $\mathrm{H}_{2} \mathrm{SO}_{4}(1 \mathrm{ml})$. The mixture was heated under reflux for $4 \mathrm{~h}$, and then neutralized with saturated $\mathrm{NaHCO}_{3}$ and extracted three times with EtOAc. TLC $\left(\mathrm{CHCl}_{3}: \mathrm{MeOH}, 95: 5, R f=0.35\right)$ analysis showed the presence of protoaescigenin in both $\mathbf{1}$ and $\mathbf{2}$ by comparison with authentic protoaescigenin.

The water layer was then condensed and divided into two parts. One part was subjected to paper chromatography and GC analysis. Glucuronic acid $(R f=0.06)$, glucose $(R f=0.19)$, and 6-deoxy-glucose $(R f=0.40)$ were detected by paper chromatography $\left[n\right.$ - BuOH-EtOH- $\mathrm{H}_{2} \mathrm{O}-$ con. $\mathrm{NH}_{3} / \mathrm{H}_{2} \mathrm{O}$, $45: 5: 49: 1]$. For GC analysis, the residue was trimethylsilyated with hexamethyldisilazane and trimethylchlorosilane in a $2: 1$ ratio at room temperature. ${ }^{13)}$ Two peaks corresponding to derivatives of 6-deoxy-glucose $\left(t_{\mathrm{R}}\right.$ : $4.18 \mathrm{~min})$ and glucose $\left(t_{\mathrm{R}}: 7.35 \mathrm{~min}\right)$ were detected consistent with the authentic samples of 6 -deoxy- $\beta$-D-glucose and $\beta$-D-glucose prepared in the same manner.

The other part was treated according to Hulyalkar's method and showed the existence of glucuronic acid. ${ }^{14,15}$ ) The retention time was $10.51 \mathrm{~min}$ (2,3,5,6-tetratrimethylsilyl- $\beta$-D-gulono-1,4-lactone). Both $\mathbf{1}$ and $\mathbf{2}$ gave the same sugars: $\beta$-glucuronic acid, $\beta$-glucose, and 6-deoxy- $\beta$-glucose.

Bioassay Antifungal assay against plant pathogenic fungus Pyricularia oryzae and the cytotoxicity assay on cultured K562 and HCT-15 cell lines were carried out as previously reported. ${ }^{16,17)}$

Acknowledgment We appreciate the kind help of Prof. Qishi Sun in Shenyang Pharmaceutical University for his collection and identification of the plant material. 


\section{References}

1) Singh B., Agrawal P. K., Thakur R. S., J. Nat. Prod., 50, 781-783 (1987).

2) Yoshikawa M., Harada E., Murakami T., Matsuda H., Watariishi N., Yamahara J., Murakami N., Kitagawa I., Chem. Pharm. Bull., 42, 1357-1363 (1994).

3) Yoshikawa M., Murakami T., Matsuda H., Yamahara J., Murakami N., Kitagawa I., Chem. Pharm. Bull., 44, 1454-1464 (1996).

4) Matsuda H., Li Y., Murakami T., Ninomiya K., Yamahara J., Yoshikawa, M., Biol. Pharm. Bull., 20, 1092-1095 (1997).

5) Yoshikawa M., Murakami T., Yamahara J., Matsuda H., Chem. Pharm. Bull., 46, 1764-1769 (1998).

6) Yang X. W., Zhao J., Cui Y. X., Liu X. H., Ma C. M., Hattori M., Zhang L. H., J. Nat. Prod., 62, 1510-1513 (1999).

7) Zhao J., Yang X. W., Cui Y. X., Liu X. H., Liu S. Y., Zhi H. Y., Chen J. R., Zhu F. B., Xue Y. L., Liu D. B., Chin. Chem. Lett., 10, 291-294 (1999).

8) Zhao J., Yang X. W., Hattori M., Chinese Traditional and Herbal
Drugs, 31, 648-651 (2000).

9) Zhao J., Yang X. W., Hattori M., Chem. Pharm. Bull., 49, 626-628 (2001).

10) Zhao J., Yang X. W., J. Asian Nat. Prod. Res., 5, 197-203 (2003).

11) Wei F., Ma L. Y., Jin W. T., Ma S. C., Han G. Z., Khan I. A., Lin R. C., Chem. Pharm. Bull., 52, 1246-1248 (2004).

12) Sakurai T., Nishimura T., Otake N., Yao X. S., Abe K., Zeida M., Nagasawa H., Sakuda S., Bioorg. Med. Chem. Lett., 12, 807-810 (2002).

13) Liu H. W., Xiong Z. L., Li F. M., Qu G. X., Kobayashi H., Yao X. S., Chem. Pharm. Bull., 51, 1089-1091 (2003).

14) Perry M. B., Hulyalkar R. K., Can. J. Biochem., 43, 573-579 (1965).

15) Chen Y. J., Takeda T., Ogihara Y., Chem. Pharm. Bull., 51, 13871394 (1985).

16) Hu K., Dong A. J., Yao X. S., Kobayashi H., Iwasaki S., Planta Med., 62, 573-575 (1996).

17) Wang S. L., Cai B., Cui C. B., Liu H. W., Wu C. F., Yao X. S., J. Asian Nat. Prod. Res., 6, 115-125 (2004). 